\title{
REZIM TANPA REZIM: KEPENATAAN DAN WACANA KOMUNISME DI RANAH PERBUKUAN INDONESIA KONTEMPORER
}

\author{
Geger Riyanto \\ Heidelberg University
}

\begin{abstract}
During the course of the New Order in Indonesia, communism and Indonesian Communist Party (PKI) as its manifestation was constructed as the nemesis of the state and even the whole nation. Communism became a taboo that everyone has to avoid or condemn. With the fall of the New Order, a lot of historical discourses about communism in Indonesia were produced to contend the official historiography. Formal discrimination through several laws and regulations against ex-PKI or allegedly communists was also stripped by the new government. However, the taboo and abjection itself is not entirely died out. In post-Reformasi Indonesia, the mechanism of rejection and condemnation to the communism has been working through many social processes. One of them is the censorship towards 'leftist publications' and persecutions towards public forums discussing 'leftist discourses', usually orchestrated by non-state actors, particularly civil or mass organizations. This article, using ethnography as its method and Foucauldian analysis of governmentality as theoretical framework, aims to discuss how such censorships and persecutions occur as a symptom of the ongoing abjection towards communism in Indonesia.
\end{abstract}

Keywords: censorship, communism, governmentality, Indonesia, publications

Correspondence author: Geger Riyanto, geger225@gmail.com, Jerman

This work is licensed under a CC-BY-NC

\section{PENDAHULUAN}

Sampai dengan detik ini-tak kurang 21 tahun sudah Orde Baru lengser-PKI dan komunisme masih menjadi momok bagi sebagian segmen masyarakat di Indonesia. Kendati kebijakan sistematik negara menyensor hal-hal yang berkenaan dengan komunisme serta menanamkan gagasan perihal buruknya ideologi, partai, maupun penganutnya sudah dilucuti, membicarakan komunisme di tengah-tengah khalayak luas tetap berpeluang menimbulkan perasaan tidak nyaman tersendiri. Beberapa tahun 
belakangan, untuk menyebut beberapa kasus yang teramati penulis, sejumlah diskusi yang mengundang para eks-tapol dihentikan paksa ormas Islam. Buku-buku yang mengulas tema komunisme, meski dalam kepentingan kajian sosial dan sejarah, dipersulit masuk ke jaringan toko buku utama. Film Jagal dilarang ditayangkan di bioskop-bioskop besar dan dinikmati para penonton, akhirnya, lewat ajang-ajang penayangan kecil-kecilan dari tempat ke tempat.

Departemen Penerangan, aparatus yang pernah menaungi kegiatan-kegiatan publikasi di negara Indonesia, boleh saja sudah dibubarkan untuk alasan tak sesuai dengan asas-asas keterbukaan yang menyertai reformasi. Lewat Presiden keempatnya, Abdurrahman Wahid, boleh saja Indonesia selaku satu pemerintahan meminta maaf kepada mereka yang mengalami diskriminasi komunis sepanjang Orde Baru, sebuah sikap etis yang dalam benak awam menengarai itikad pemerintahan baru membuka keran kebebasan. Akan tetapi penyaringan materi-materi yang memiliki nuansa komunisme, dalam satu bentuk yang lain, terus bergulir. Tanpa otoritas formal, tabutabu terus dilestarikan. Tanpa kepentingan yang jelas - di mana pengertian jelas berarti punya resonansi dengan situasi ekonomi politik yang luas - ketakutan warisan usang era Perang Dingin dan Orde Baru ini hidup dan berdenyut kuat.

Situasi yang sekilas kontradiktif ini kontan mengingatkan penulis dengan tesis kepenataan (governmentality) yang diajukan oleh Foucault (2008). Proses penertiban, dalam argumentasi Foucault, tidak melulu bekerja lewat paksaan kekuatan-kekuatan eksternal dari luar diri subjek yang mengalaminya. Kekuasaan, bila ia ingin merentangi satu wilayah ruang dan waktu yang ekstensif, hanya dimungkinkan manakala ia bekerja terpencar-terdispersi. Lewat tesis kepenataan, secara spesifik, Foucault mengajak pembacanya memikirkan bahwa kekuasaan dalam aktualisasinya hanya mungkin untuk efektif lantaran beroperasi pada berbagai tataran secara sekaligus. Ia tak hanya kekuasaan yang tersemat pada institusi formal negara, melainkan dipraktikkan oleh interaksi di antara setiap pihak maupun mentalitas diri yang terlibat dalam jejaring keteraturan bersangkutan. Berbicara kekuasaan adalah berbicara kondisi yang diproduksi oleh setiap momen kehidupan sosial itu sendiri; lantaran para subjek mengkreasikan sendiri ketertiban agar berjalan beriringan dengan kepentingannya, kekuasaan pun dimungkinkan bertransformasi dan lentur berpadanan dengan situasi sesaat, partikular berbagai subjek yang mengalaminya.

Fenomena penabuan komunisme pasca-Orde Baru di Indonesia menunjukkan kepada kita bagaimana situasi kepenataan dan rezim otoriter merupakan dua hal yang tak saling mensyaratkan satu sama lain. Penertiban tidaklah identik dengan satu pusaran pengendalian melainkan bergulir menyelaraskan diri dengan aktivitas yang majemuk baik dalam hal jenis maupun kuantitas - di mana dalam kasus ini, ia lebih perlu melapih kepada aktivitas-aktivitas yang nyata ketimbang kepada strukturstruktur formal. Berangkat dari argumentasi Foucault, penelitian ini berusaha memahamkan kepada pembacanya bagaimana kekuasaan bekerja secara aktual yakni melalui peristiwa dan proses ini akan dikasatmatakan dengan mengulas keterjadiannya lewat kasus kesukaran memperbincangkan komunisme pada ranah perbukuan Indonesia kontemporer.

Permasalahan yang coba didekati di artikel ini dapat dirumuskan dalam bentuk pertanyaan penuntun. Pertama, apa yang menyebabkan wacana komunisme masih sukar untuk diperbincangkan secara terbuka bahkan selepas tak efektifnya kekuasaan Orde Baru? Kedua, bagaimana kekuasaan bekerja secara aktual lewat proses-proses 
nyata di luar struktur kekuasaan formal yang biasa kita bayangkan sebagai pemegang kekuatan utama?

\section{METODE PENELITIAN}

Dalam proses penelitian ini, peneliti memanfaatkan tiga teknik untuk menghimpun data yang dianggapnya paling efektif sekaligus relevan untuk memperoleh informasi empiris yang diperlukan. Pertama, pengamatan terlibat. Peneliti, yang ambil bagian dalam ranah penerbitan sejak 2009 akhir, telah memperoleh berbagai informasi tak tergantikan dari ranah ini tentang bagaimana proses-proses sosial khas di dalamnya berlangsung. Maksud saya tak tergantikan, informasi yang saya peroleh dari periode keterlibatan ini adalah pengalaman yang tak mungkin saya dapatkan apabila mendatangi aktor-aktor dalam proses produksi buku dan mewawancarai mereka sebagai orang dari luar lingkungan perbukuan dalam waktu singkat; antara lain, untuk merunut beberapa, pengalaman mencerap pemajangan buku-buku bertajuk komunisme di toko-toko buku, jejaring internal beserta informasi-informasi yang beredar yang tampaknya tak akan mudah menyebar kepada orang yang baru terjun ke ranah ini, pemahaman mendalam tentang proses yang dipelajari dari keikutsertaan yang memungkinkan saya memilah maupun mengonfirmasi data-data wawancara yang saya peroleh. Pada kesempatan ini, penulis mencoba mengilas apa yang pernah peneliti alami di ranah perbukuan dan mengidentifikasi informasi-informasi yang relevan bagi pertanyaan penelitian.

Kedua, wawancara. Wawancara dilakukan terhadap lima aktor yang peneliti timbang tepat untuk menguraikan kondisi-kondisi aktual dari segmen ranah penerbitan yang penting andilnya bagi. Seperti yang telah disebutkan sebelumnya, pengamatan terlibat penulis bermanfaat mengevaluasi reliabilitas dari data wawancara. Berkat pengamatan terlibat, memang, peneliti jadi mungkin mengetahui, misal, pada bagian mana satu informan beretorika untuk mengimpresi peneliti dan pada bagian mana ia menyampaikan data faktual yang bisa dipastikan kesahihannya. Namun hal sebaliknya juga akan berlaku. Data pengamatan terlibat, selain dilengkapi, juga akan dievaluasi berdasarkan teknik penghimpunan data kedua ini. Banyak hal sebenarnya yang tak pernah peneliti ketahui meski telah terlibat lama di penerbitan; struktur distributor dan Gramedia secara pasti, sebut saja. Proses penyulitan yang dialami penerbit juga sebelumnya hanya pernah penulis dengar dari kabar yang beredar dan, kini, mungkin untuk dikonfirmasi serta diperoleh detailnya. Di sinilah wawancara berfaedah melengkapi informasi proses-proses yang ditempuh penerbitan buku bertajuk komunisme. Di sisi lain, wawancara juga memeriksa apakah misal pengalaman dipersulit atau dihalau juga dialami oleh penerbit-penerbit lainnya. Teknik ini diperiksa sekaligus memeriksa data yang diperoleh dari teknik penghimpunan lainnya.

Wawancara pertama dilakukan kepada JJ Rizal, pemilik Komunitas Bambu, penerbit yang mengkhususkan diri mempublikasikan buku-buku sejarah dan salah satunya Kemunculan Komunisme di Indonesia yang pada masa Orde Baru pernah dilarang pemerintah. Kedua, wawancara dilangsungkan kepada Martin Noverius, staf bagian pembelian distributor buku Serambi. Ketiga, wawancara masih dilangsungkan kepada staf bagian pembelian Serambi, Taufik. Keduanya memiliki karakter yang 
berbeda di mana yang pertama lebih gemar mengobrol sementara yang kedua lebih senang menjawab seadanya dan agak cuek. Mengulang beberapa pertanyaan serupa kepada keduanya, konsistensi atau kontradiksi pada jawaban keduanya memang saya harapkan dapat mengonfirmasi informasi yang diberikan masing-masing. Wawancara kepada keduanya dilangsungkan di dua hari yang berbeda dan terpisah, sehingga konsistensi informasi tidak disebabkan mereka diwawancara berbarengan.

Keempat, wawancara kepada Ronny Agustinus, kepala penerbitan Marjin Kiri. Menerbitkan buku Wijaya Herlambang, Marjin Kiri merupakan satu dari sedikit penerbit yang memublikasikan buku-buku wacana tandingan dan memperoleh tempat tersendiri di antara pembacanya sebagai penerbit tema yang disegani ini. Ronny, saya kira, merupakan informan yang tepat untuk menggali kepentingan dan rasionalitas menerbitkan buku bertajuk ulasan terhadap komunisme. Kelima, Cak Tarno. Sebagai pedagang buku yang berkonsentrasi pada buku-buku sosial-humaniora, Cak Tarno bukan hanya menjual melainkan juga memperoleh informasi langsung bagaimana para pembeli mencari buku di lapaknya dan tentu saja motif mereka meminatinya. Peneliti seharusnya juga mewawancarai pihak Gramedia, selaku jaringan toko buku utama. Namun pihak yang justru memiliki peranan penting dalam penentuan buku yang layak dan tidak layak diedarkan toko, yang artinya krusial mempengaruhi proses penerbitan ini, tidak bersedia diwawancara setelah penulis menyampaikan tema penelitian penulis.

Teknik pengumpulan data ketiga adalah studi dokumen, pemberitaan, dan kepustakaan. Peneliti menelisik sumber-sumber kepustakaan, pemberitaan, maupun dokumen untuk mengilas berbagai peristiwa penting yang menandai momen-momen perubahan atau yang mengindikasikan kerja genting dari formasi sosial yang penulis teliti. Informasi-informasi tertulis ini penting untuk memastikan, misal, tanggal kejadian suatu peristiwa yang penting, mengecek detail-detail yang kabur dari peristiwaperistiwa bersangkutan, serta memperoleh sejumlah informasi baru yang belum tertangkap dari dua teknik sebelumnya. Berbagai informasi disampaikan informan atau tercerap penulis. Namun berbagai hal di dalamnya beberapa kali baru dapat diperoleh detail kecilnya setelah pengecekan terhadap sumber-sumber tertulis ini.

\section{HASIL DAN PEMBAHASAN}

\section{Dari Pelarangan Menuju Kepenataan Baru}

Selepas reformasi, ranah penerbitan buku-buku bertema sosial-humaniora sempat semarak mengikuti kian mudahnya proses-proses penerbitan di Indonesia. Peredaran barang-barang cetakan semakin leluasa seiring diblejetinya otoritas organorgan pemerintah yang secara efektif berwenang mengontrolnya. Pada Agustus 1998, di tengah-tengah krisis ekonomi yang juga mendera industri perbukuan, Yayasan Ford juga bekerja sama dengan Adikarya Ikapi mencurahkan dana untuk penerbitan bukubuku berperspektif ilmu sosial yang dianggap bisa mendorong demokratisasi di Indonesia. Pada tahun-tahun ini, kita menjumpai LKiS menerbitkan buku-buku Islam dengan tema yang tak bisa dibilang arus utama. Insist dan Resist Book menerbitkan buku-buku yang umumnya bertema kritik terhadap model-model pembangunan arus utama. Banyak di antara buku-buku yang terbit pada periode awal 2000-an ini sebenarnya merupakan terjemahan dari buku-buku yang tak tergolong dalam buku 
populer melainkan kajian-kajian akademis atau, bila dari penulis Indonesia, merupakan karya akademis mereka. Melonjaknya suplai buku-buku akademik bertema sosialhumaniora yang diikuti dengan peningkatan permintaannya ini pun mendorong kemunculan sejumlah penerbit yang bergelut pada isu-isu yang, bila kita bandingkan dengan ranah penerbitan di beberapa negara lain, terkategori dalam buku-buku akademik yang tak memiliki basis pembaca populer. Pasar yang relatif ajeg untuk bukubuku sosial-humaniora tumbuh.

Hal yang juga patut dicermati adalah penerbit yang gencar mewarnai boom buku ini sebagian besar merupakan penerbit menengah atau bahkan kecil. Bukannya penerbitan besar seperti Gramedia tidak ambil andil namun, mengikuti mudahnya proses penerbitan yang kini bahkan tak memerlukan badan hukum yang legal, penerbitan kecil ke menengah begitu marak bertumbuhan pada rentang waktu ini. Ada pula penerbitan yang bahkan diampu hanya oleh satu-dua orang. Sebagian penerbitan ini, perlu dicatat pula, berdomisili di Yogyakarta. Hal yang sangat bisa dipahami pasalnya Yogyakarta mengasup banyak lulusan perguruan tinggi-kelompok yang lebih acap tersentuh dengan teks-teks akademik sekaligus terbekali pemahaman untuk mengolahnya-yang dengan sendirinya menyediakan produsen sekaligus konsumen bagi buku. Pada saat yang sama, di Yogyakarta biaya-biaya produksi yang lebih rendah dibanding kota lain yang memiliki banyak institusi pendidikan tinggi seperti Jakarta. Faktor khas, yakni citra kecendekiawanan sebagai preferensi diri ideal, juga patut diperhitungkan sebagai aspek yang mendorong kota ini bertumbuh sebagai pusat penerbitan buku-buku sosial-humaniora akademis di Indonesia.

Kendati demikian, situasi riuh-rendah perbukuan ini tak serta-merta diikuti dengan keleluasaan dari pantauan otoritas negara. Terlepas penerbitan pada periode ini mungkin untuk memproduksi dan mendistribusikan bukunya pada jaringan-jaringan toko buku besar cukup dengan meminta ISBN kepada Perpustakaan Nasional, Kejaksaan Agung masih memiliki otoritas untuk melarang peredaran buku. Buku-buku yang dianggap dapat mengampanyekan komunisme, yang pada masa Orde Baru merupakan target utama pembredelan, masih rentan ditarik dari peredaran biasanya dengan dalih dapat mengganggu keamanan. Dasar hukum yang dimanfaatkan oleh Kejaksaan Agung adalah UU No. 4/PNPS/1963, produk hukum yang dikeluarkan pada masa Demokrasi Terpimpin yang mengatur peredaran barang-barang cetakan yang dianggap berpotensi mengganggu ketertiban umum. Pada masa Orde Baru, buku-buku yang bahkan dianggap sekadar lekat dengan komunisme - terbitan beraksara Tiongkok, ambil saja - dilarang dengan ketat peredarannya. Sistem pengaturannya, lumrahnya, Kejaksaan Agung menerima pengaduan. Pengaduan bersangkutan kemudian ditinjau dan, proses selanjutnya, bila terbitan terkait dianggap meresahkan, SK pelarangan akan dikeluarkan. Proses pemantauan dan pengaduan jamak dilakukan berbagai lembaga negara antara lain Bakin (Badan Koordinasi Intelijen Negara), Bakorstanas (Badan Koordinasi Stabilitas Nasional), Bais (Badan Intelijen Strategis), ABRI (Angkatan Bersenjata Republik Indonesia), Polri (Kepolisian Republik Indonesia), dan Departemen Agama. Pada tahun 1989, kerja sama pelaporan dan pelarangan antara berbagai lembaga negara ini diformalkan dengan pendirian Clearing House, lembaga antarinstansi yang berada di bawah kewenangan Kejaksaan Agung yang fungsinya adalah meneliti isi terbitan dan memberi rekomendasi kepada Jaksa Agung.

Pada dasarnya, Clearing House ini masih efektif bahkan selepas demokratisasi di Indonesia. Namun dengan kentalnya sentimen negatif terhadap komunisme pada 
masa Orde Baru seiring ia dimanfaatkan sebagai perkakas memberangus ancaman terhadap rezim, hukuman yang mungkin untuk dialami seseorang yang tertuduh menyebarkan publikasi-publikasi yang mengadvokasi komunisme dengan sendirinya lebih berat. Pada tahun 1989, sebagai misal, tiga pemuda di Yogyakarta divonis hukuman empat tahun penjara lantaran didapati memiliki buku Rumah Kaca karya Pramoedya Ananta Toer. Adapun, masih pada masa ini, buku-buku akademik dapat memperoleh pengecualian hingga kadar tertentu, namun hanya setelah dalam kajian organ pemerintah ia tetap dianggap tidak akan mengganggu ketertiban umum. Akibatnya, kalaupun bisa lolos dari larangan, buku-buku ilmu sosial yang ditaksir mempergunakan istilah-istilah yang punya resonansi dengan diskursus yang digadang komunisme mengalami penyuntingan yang tak jarang konyol terlebih dahulu. Buku Ralf Dahrendorf yang dalam judul aslinya Class and Class Conflict in Industrial Society, sekadar satu contoh, mengalami penyuntingan menjadi berjudul Konflik dan Konflik dalam Masyarakat Industri sebelum ia diterbitkan oleh penerbit Rajawali. Namun lagilagi, batasan dalam pelarangan ini sama sekali kabur dan mudah diulur secara seenaknya. Beberapa buku yang nyata-nyata dalam kajiannya tak mengadvokasi komunisme, hanya menelaahnya sebagai subjek kajian sejarah atau sosiologi, namun, memang, katakan saja, mencetuskan kata komunisme atau PKI secara gamblang - misal, menaruhnya di sampul-dilarang peredarannya.

Regulasi terhadap buku relatif melunak mengikuti kejatuhan Orde Baru. Bukubuku bertema kritik terhadap pemerintahan, memoar sejarah yang kontroversial, ulasan perbandingan agama, karya sastra yang sebelumnya dianggap dikarang penulis Lekra mungkin untuk diterbitkan atau diedarkan. Pelunakan ini terjadi rasanya juga tak lepas lantaran membeludaknya jumlah buku bertema sosial-humaniora berkat subsidi FordIkapi dan, pada saat yang sama, euforia demokratisasi. Yang terjadi dalam berbagai kesempatan, kejaksaan memblejeti buku-buku yang rata-rata secara eksplisit mencantumkan pada judulnya simbol-simbol yang provokatif dan mengisyaratkan substansi yang akan mengulas tema yang kelewat tabu bagi kekuatan-kekuatan tertentu. Beberapa buku bertema sosial-politik yang dilarang oleh Kejaksaan Agung pada masa reformasi antara lain Dalih Pembunuhan Massal: Gerakan 30 September dan Kudeta Soeharto, Suara Gereja bagi Umat Tertindas: Penderitaan Tetesan Darah dan Cucuran Air Mata Umat Tuhan di Papua Barat Harus Diakhiri, Lekra Tak Membakar Buku: Suara Senyap Lembar Kebudayaan Harian Rakjat 1950-65, Aku Bangga Menjadi Anak PKI, Pembunuhan Theys: Kematian HAM di Tanah Papua. Sejumlah judul yang terpapar barusan secara terang-terangan memang menyajikan substansi yang kontroversial bagi kekuatan-kekuatan tertentu dan pelarangan buku Dalih Pembunuhan Massal Roosa secara khusus menunjukkan dalih kajian akademis masih belum bisa mengamankan karya yang mengesankan akan menyentuh tema sensitif. Buku-buku sejarah SMP dan SMA yang tak mencantumkan PKI sebagai pelaku G-30-S juga mengalami pemberangusan pada 2007. Sebanyak 22 judul buku pelajaran dibakar dan peristiwa ini menuai perhatian yang tak kecil.

Namun, yang sebenarnya paling penting diperhatikan, pada periode ini kita menyaksikan modus kepenataan yang berangsur mulai bergeser. Masih efektifnya Clearing House yang lazimnya beranggotakan pejabat-pejabat kalangan militer atau, setidaknya, punya habitus militer, memungkinkan materi-materi yang dianggap membahayakan atau bahkan sekadar menggoyahkan kredibilitas kelompok ini diawasi. Pada saat yang sama, kekuatan-kekuatan sipil koersif yang disegani untuk 
kemampuannya memobilisasi massa mulai menjamur. Kekuatan-kekuatan sipil yang lumrahnya berpijak pada identitas agama inilah yang akan ambil andil dalam pembentukan modus kepenataan baru yang menghambat produksi diskursus komunisme di ranah perbukuan. Pada 3 Juli 2010, diskusi buku karya para tapol 1965 yang diselenggarakan di Sanata Dharma digerebek oleh sekelompok orang bersenjata. Di Yogyakarta, terbentuk sebuah ormas bernama Front Anti Komunis Indonesia (FAKI) dan bersama polisi ormas ini sempat merazia buku-buku bertema komunisme, Marxisme, Leninisme. Ormas yang mengedepankan simbol-simbol Islam ini sempat menimbulkan berita nasional pula dengan membubarkan Kongres Partai Persatuan Pembebasan Nasional (Papernas) pada awal 2007.

Keresahan terhadap pelarangan buku, di satu sisi, menimbulkan gerakan perlawanan di antara kelompok-kelompok sipil tertentu. Permintaan-permintaan uji materiil terhadap UU No. 4/PNPS/1963 diajukan oleh sejumlah kalangan kepada Mahkamah Konstitusi; UU ini dianggap merupakan warisan era otoriter yang sudah tidak relevan lagi. Berbagai kelompok intelektual secara rutin mengeluarkan pernyataan sikap menentang pelarangan buku. Salah satunya, yang melibatkan banyak pihak, adalah pernyataan sikap dari Masyarakat Pecinta Buku dan Demokrasi pada 2007. Kelompok ini mengecam pelarangan buku sebagai tindakan biadab yang tak ayalnya perilaku fasis sebagaimana pernah dilakukan Nazi. Kelompok ini mengajukan petisi yang ditandatangani puluhan tokoh dan aktivis dari mantan presiden, Abdurrahman Wahid, advokat, Todung Mulya Lubis, akademisi, Daniel Dhakidae dan Frans Magnis Suseno, dan lain-lain. Pengiriman surat protes dan buku yang dilarang kepada otoritas bersangkutan, penggalangan dukungan lewat ekspresi kesenian, atau diskusi buku terbatas maupun kampanye di internet dilangsungkan oleh pihak-pihak yang menuntut pelarangan buku dicabut. Namun, di sisi lainnya, di samping gerakan yang menggugat paradoks kebebasan berpikir di era reformasi, aliansi kekuatan baru tengah menata diri sebelum ia menjadi struktur yang tak gamblang namun nyata mengungkung peredaran buku-buku dengan tema yang dianggap sensitif.

Waktu yang dinanti-nanti terjadi pada bulan Oktober 2010. Mahkamah Konstitusi akhirnya membatalkan UU No. 4/PNPS/1963 yang artinya mencabut kewenangan Kejaksaan Agung dalam melarang buku. Lewat keputusan yang disambut para aktivis HAM, kebebasan, dan perbukuan ini, aktor yang telah lama menjadi kekuatan yang dapat secara sepihak mengancam peredaran buku tak memiliki lagi kewenangan formal untuk melakukannya. Tak lama sebelum keputusan ini diambil oleh MK, sebuah buku bertema kajian akademik terhadap komunisme yang sempat dilarang pada era Orde Baru sebenarnya sudah beredar. Buku tersebut-Kemunculan Komunisme di Indonesia karya McVey, pertama kali diterbitkan dalam versi bahasa Inggrisnya oleh Cornell University pada 1965-beredar di toko-toko buku jaringan utama pada awal tahun 2010. Buku ini sempat, tampaknya, ragu untuk dipajang oleh jaringan toko buku Gramedia. Biasanya sebuah buku akan mulai dipajang di toko buku paling tidak dua minggu setelah pihak distributor, perantara antara penerbit dan toko buku, menerima buku bersangkutan dari penerbit pada waktu yang ditetapkan untuk sebuah terbitan masuk ke mereka. Namun melewati waktu tersebut, buku Kemunculan Komunisme belum kunjung terpajang di toko buku. Pihak penerbit, Komunitas Bambu, akhirnya menghubungi distributor yang masih satu perusahaan dengan Gramedia sendiri. Buku tak lama kemudian barulah terpajang di jaringan toko buku utama ini. 
Buku ini, tanpa diduga, memperoleh sambutan yang cukup baik di antara pembaca. Kemunculan Komunisme termasuk di antara buku jajaran terlaris pada awal Januari 2010 yang dijual oleh Komunitas Bambu. Di beberapa toko buku Gramedia maupun jaringan toko buku lainnya, buku ini sempat pula menempati rak buku terlaris untuk tema sejarah atau sosial-humaniora. Setelah lama buku yang secara terbuka bertajuk komunisme dan tak termasuk terbitan yang didukung pemerintah dihalau beredar luas, pembaca kini bisa memperolehnya kembali di jaringan toko buku utama. Di tahun berikutnya selepas kewenangan kejaksaan mengatur peredaran buku diblejeti, sejumlah terbitan yang tak enggan menaruh tema komunisme pada judulnya mengikuti terbit. Beberapa di antaranya adalah terbitan dari Komunitas Bambu lagi - Penghancuran PKI karya Olle Tornquist-kemudian dari penerbit Yogyakarta, Pustaka Pelajar, Communism Under Sukarno karya Rex Mortimer. Masing-masing karya ini merupakan terjemahan dari kajian akademik peneliti Barat. Buku pertama, dari Tornquist, sebagaimana karya McVey, tak diperkenankan untuk terbit semasa Orde Baru. Dibanding buku-buku lainnya, buku Penghancuran PKI Tornquist pun memiliki sampul edisi Indonesia yang lebih angker. Bukan hanya bernuansa gelap kemerahan, sampul buku ini juga berilustrasi simbolik satu sosok yang tak terlihat kepalanya berdiri sembari menyembunyikan arit di belakangnya. Font sampulnya berjenis grunge. Tak salah bila menyebut sampul buku ini mengingatkan pada publikasi-publikasi agitasi atau propaganda.

\section{Kepenataan dan Batasan yang Diperformakan}

Kendati menggoda untuk mengatakan situasi ini sebagai pencapaian perjuangan kebebasan berpikir dalam ranah perbukuan, kebebasan sebagai terma yang mengisyaratkan kelepasan, keleluasaan aktor manusia dari daya-daya yang mengaturnya tidaklah terlalu tepat digunakan untuk menggambarkan keadaan kontemporer yang kita hadapi. Keliru, pada khususnya, bila menganggap kungkungan dan regulasi hanya berasal dari otoritas negara. Organ-organ negara - tak didikte oleh satu rezim yang relatif terpusat dan terdiri dari elite-elite yang lebih terbatas kalangannya sebagaimana era Orde Baru - tak punya kepentingan yang sama kuatnya untuk menegakkan ketertiban dengan nuansa militeristis dibandingkan di masa silam. Senantiasa berada di antara pergulatan berbagai kepentingan, adalah galat untuk menganggap manusia punya satu kondisi yang murni bebas, lepas, tak terpaut dengan daya apa pun di luar kesadarannya. Namun satu hal yang juga pasti: keliru untuk mengobjektivasi kekuatan yang bekerja di luar diri sang aktor sebagai tatanan tunggal yang baku. Tiap tindakan akan selalu dihadapkan dengan kondisi yang melingkupinya namun kondisi ini bukanlah situasi umum yang impersonal maupun alami berada di luar konstruksi para aktor. Lebih tepat, karenanya, untuk mengatakan, sebuah tindakan akan selalu dihadapkan dengan tindakan-tindakan aktor lainnya. Apa yang menghalau, membentuk, menjuruskan tindakan seorang aktor bukanlah struktur yang tak bergerak dan tak akan lekang melainkan aksi aktual dari aktor-aktor lainnya. Pada satu momen, pertemuan antara berbagai tindakan dari jejaring aktor yang berbeda-beda ini akan merampungkan satu sinkroni yang ringkih yang tak seyogianya kita perlakukan sebagai mekanisme-mekanisme sosial yang abadi.

Berpijak dari argumen ini-dan temuan yang sebentar lagi akan saya uraikansaya mengambil jalur yang berbeda dari penelitian-penelitian sebelumnya terhadap 
formasi wacana antikomunisme di Indonesia. Tidak ada, saya mengambil jalur imanensi yang dirintis Foucault di sini, yang berkedudukan lebih transenden atau mempunyai bobot ontologis lebih tinggi dibandingkan yang lain. Setiap momen dan sisi dari kehidupan sosial adalah peristiwa yang, artinya, berlangsung di ruang yang disesaki dengan para aktor dan rasionalitasnya masing-masing alih-alih tersegregasi di antara kekuatan tak tersentuh yang menentukan - atau sebut saja struktur-dan aktor yang sekadar wahana realisasi dari tatanan bersangkutan. Apa yang dirujuk oleh Heryanto sebagai narasi pokok komunisme sebagai liyan dan menjadi tolakan Herlambang serta McGregor untuk menelaah subjek-subjek telitiannya tak lain sebagai representasi dari narasi ini pokok ini, pada praktiknya, bukanlah tatanan yang mengambang atau ahistoris. Ia, kalaupun mesti dikatakan ada, mestilah senantiasa dilakoni dan dipraktikkan sebagai syarat keberlangsungannya dalam kehidupan sosial yang aktual. Ia bukanlah fakta sosial yang bisa diperlakukan selaku objek konkret, sebagaimana yang diusulkan Durkheim kepada kita, melainkan teks yang punya asal-usul kesejarahan tertentu dan dijaga bukan hanya oleh kepentingan para elite melainkan juga secara menyehari oleh para aktor awam yang menerjemahkannya dalam iringan realisasi kepentingan tiap-tiap aktor ini.

Dengan sendirinya, perlakonan narasi pokok ini pada satu jejaring aktorkepentingan dan jejaring aktor kepentingan yang lain dapat dipastikan akan berbeda. Pada saat kita berusaha untuk melacak kesepadanan di antara narasi-narasi komunisme yang berkembang di berbagai wilayah kehidupan di Indonesia, sebagaimana yang akan dilakukan telaah strukturalisme, dan telah dilakukan oleh McGregor dan Herlambang, kita dipastikan akan menemukannya. Kesepadanan di antara berbagai praktik diskursif ini lumrah pula dianggap menunjuk kepada satu tatanan yang memaksa para aktor yang begitu beragam untuk bertindak demi keutuhan tatanan bersangkutan. Namun, saya akan menukil Foucault di sini, tak memadai memahami kerja rezim diskursif dengan logika sebagai satu kekuatan ia membatalkan yang lain; pasalnya, saat cukup seksama kita ikuti, kepentingan masing-masing tetap berjalan dalam sebuah tindakan yang mengumbar ketaatan sekalipun. Yang terjadi dalam proses-proses yang acap kita anggap sebagai penguasaan satu pihak kepada pihak lain adalah pergerakan yang sifatnya strategis ketimbang dialektis. Satu pihak dalam posisi yang tak memiliki keleluasaan yang sama dengan segelintir insan yang disebut elite untuk memobilisasi sumber daya tentu tak akan bisa semudah para elite dalam menepis kekangankekangan, katakanlah, yang menghalau proses pencapaian tujuannya. Namun ia dipastikan, entah apa caranya, akan menegosiasikan kepentingannya agar tak begitu saja tergerus. Pada akhirnya, apa yang kita sebut sebagai diskursus antikomunisme di sini bukanlah sebuah skema pendikte kenyataan empiris yang tak akan pernah terjamah melainkan, saya ingin menyebutnya, sebuah aliansi yang berjalan karena saling menunaikan kepentingan masing-masing.

Pertanyaannya, kini, aliansi di antara kepentingan-kepentingan apa? Siapa aktornya? Saya ingin membuka peluang seluas-luasnya sebagaimana yang dilakukan Bruno Latour dengan memberi tempat kepada aktor nonmanusia: di antara semua daya yang mungkin untuk menorehkan perbedaan dengan kehadirannya di antara jejaring tindakan yang ada. Rezim legal-formal hanyalah satu di antara nebula kekuatan yang melansir situasi medan perbukuan sebagaimana yang sekarang terbentuk. Yang paling penting bukanlah melacak kekuatan yang kita bayangkan memiliki otoritas melainkan aktor-aktor yang berperan riil dalam proses spesifik itu sendiri-dalam hal ini, proses 
penerbitan buku dengan tema tertentu. Kita, karenanya, sama sekali tak memprioritaskan untuk berbicara otoritas formal melainkan otoritas yang partikular sekaligus nyata bekerja di antara proses yang kita teliti. Kini pertanyaannya, siapa? Saya akan mengatakan, mereka yang terlibat dalam rantai produksi buku dari naskah hingga diterima pembacanya serta keresahan-keresahan lama yang ternyata terus-menerus direproduksi untuk melanggengkan kepentingan-kepentingan yang tak harus kebutuhan ekonomi-politik.

Dalam proses penerbitan, hal yang paling bisa dipastikan akan menjadi pertimbangan sebuah penerbitan komersil adalah perputaran uang dari keterjualan bukunya di pasaran. Kita bisa memilah penerbitan menjadi penerbitan komersil, di mana produksi buku berbasis pada keterjualan bukunya, dan penerbitan bersponsor, di mana produksi buku berbasis kepuasan penyandang dana tertentu. Sejauh yang saya amati, sejak Kemunculan Komunisme di Indonesia belum pernah ada sebuah buku bertajuk komunisme yang disponsori satu pihak di luar penerbitan itu sendiri. Dalam situasi demikian, pemilihan tema komunisme paling pertama selain didasarkan pada preferensi tematik penerbit bersangkutan harus dihadapkan dengan peluang keterjualan buku terkait. Kedua pertimbangan ini mesti dimungkinkan untuk berjalan beriringan bila sebuah penerbitan, sebagai badan usaha, menghendaki aktivitasnya berkesinambungan. Biaya yang dihabiskan untuk penerbitan sebuah buku tidaklah kecil. Buku Kemunculan Komunisme di Indonesia setebal 688 halaman dan bersampul keras, dari taksiran percetakan dan penerbitan yang menelaahnya, menelan biaya produksi yang bisa mencapai Rp100 juta. Belum lagi, penerbitnya, Komunitas Bambu, menerbitkan dua hingga empat buku setiap bulannya. Selepas tahun 2010, tak ada satu skema subsidi yang masif dan berkesinambungan terhadap buku-buku sosialhumaniora lagi sebagaimana yang dicurahkan Ford terdahulu. Kalaupun sebuah buku bisa memperoleh subsidi, ia biasanya disponsori oleh satu pihak yang tak punya kepada penerbitan buku yang kontinyu melainkan hanya kepada satu naskah yang mereka rampungkan. Pihak-pihak ini lumrahnya adalah lembaga kajian atau penulis sendiri. Penerbitan tertentu yang cukup memiliki nama dan sempat mengkhususkan diri dalam penerbitan buku-buku tematik sosial-humaniora, seperti Kepustakaan Populer Gramedia, dapat memperoleh pendanaan dari berbagai lembaga untuk menerbitkan buku-buku berperspektif ilmu sosial dalam beberapa waktu lamanya. Namun skema ini pun terbukti tidak terjamin kontinuitasnya.

Dengan kondisi demikian, keberlangsungan penerbitan pun sebagaimana berbagai usaha pada wajarnya menjadi berandal pada seberapa mungkin produknya terjual kepada konsumen pasar luas. Memahami situasi ini juga memungkinkan kita memahami mengapa tema komunisme sempat relatif marak diterbitkan pada 2010-11. Buku yang dapat menyajikan dirinya membawakan satu tema yang dipersepsi khalayak ramai kontroversial mempunyai peluang lebih untuk meraih perhatian lebih banyak calon pembeli. Upaya Komunitas Bambu mengemas buku Penghancuran PKI dengan sampul dan judul yang membangkitkan asosiasi agitasi PKI dapat kita pahami sebagai upaya meraih perhatian publik penikmat buku. Dengan ekses-ekses diskursus anti-PKI yang pernah marak namun tak lagi-setidaknya untuk sementara waktu-memiliki otoritas pencekalan buku yang efektif, penerbit melihat momen ini sebagai kesempatan strategis mempublikasikan terbitan-terbitan bertema komunisme. Tema yang punya impresi terlarang dianggap akan menuai respons yang lebih kuat dibandingkan bukubuku bertema sosial-humaniora lainnya. 
Tetapi, yang juga patut dicermati, jalur-jalur distribusi kepada konsumen serta pengaturannya pun menjadi penting bagi penerbitan tak bersubsidi. Pada tahun 2012, terjadi setidaknya dua peristiwa yang bisa kita pastikan punya dampak tak tergantikan bagi proses produksi wacana lewat ranah buku. Pembakaran buku 5 Kota Paling Berpengaruh di Dunia terbitan Gramedia dan sentralisasi jaringan toko buku utama ini. Sebagai rantai hilir dalam proses penerbitan buku, toko buku Gramedia merupakan gerai yang paling dominan dalam proporsi penjualan dibandingkan gerai-gerai buku lainnya. Satu distributor menaksir penjualan Gramedia dibandingkan seluruh toko buku non-Gramedia lainnya digabungkan bisa mencapai 60:40. Belum lagi, selain dengan dominasinya dalam total penjualan buku serta jaringan yang melingkupi berbagai pelosok Indonesia, jaringan toko buku utama ini juga terbilang yang paling dalam pembayaran serta pelaporan. Keraguan pemasok buku mensuplai terbitanterbitannya ke jaringan-jaringan toko buku tertentu kerap semata dikarenakan jaringan bersangkutan tak disiplin dalam melakukan pembayaran atau memanipulasi laporan penjualan.

Dua peristiwa yang melibatkan jaringan toko buku utama yang saya sebutkan di atas, didorong juga dengan situasi semakin membeludaknya jumlah buku di pasaran, menyebabkan bentuk pengontrolan baru terhadap buku perlahan-lahan rampung. Tak berselang lama sejak peristiwa pembakaran buku lantaran kecaman FPI yang mendakwa satu bagian di buku ini melecehkan Muhammad-dan diduga pula ada motif pemerasan yang bermain - penyeleksian terhadap buku-buku yang dapat masuk ke toko Gramedia mengalami pengetatan. Terbitan-terbitan bertema agama diperketat penyaringannya untuk mencegah peristiwa yang sama berulang. Satu penerbit yang sempat hendak menerbitkan buku kajian penghancuran PKI 1965 dari karya disertasi sosiologi diminta untuk menunda proses penerbitan buku bersangkutan. Beberapa waktu selepas peristiwa ini dan seiring proses sentralisasi Gramedia, yang menyebabkan toko buku utama ini hanya menerima buku lewat satu pintu, berbeda dengan sebelumnya di mana tiap toko dapat memasok buku berdasarkan pilihan divisi pembelian masing-masing toko, proses masuknya sebuah buku tak sesederhana lagi sebagaimana periode singkat antara pembubaran Clearing House dan pertengahan 2012. Gramedia dapat menolak buku berdasarkan keputusan sepihak. Tak ada batasan tertulis yang jelas, dapat dipastikan, dan konsisten berlaku - buku yang sebelumnya sudah disetujui sekalipun oleh distributor Gramedia, yakni buku Teror Soeharto, akhirnya bernasib ditolak oleh toko bukunya kendati sudah dicetak sebanyak 3.000 eksemplar. Para penerbit serta distributor, konsekuensinya, harus meraba sendirisendiri batas yang tak boleh mereka terabas. Mereka bisa berkonsultasi dengan bagian pembelian Gramedia namun tak ada yang menjamin pikiran pihak yang berwenang tak berubah di kemudian hari.

Seketika satu judul tak diperkenankan beredar di Gramedia, penerbit bisa dipastikan akan mengalami kerugian yang tak kecil. Bila dulu ada ungkapan pelarangan buku berarti promosi gratis, permasalahannya kalaupun benar satu buku menjadi tersohor karena dihambat akankah keuntungannya ditangguk oleh pihak yang berinvestasi paling besar untuk terbitnya buku bersangkutan - hal yang memastikan buku dengan tema semacam secara konsisten diproduksi? Hal yang paling mungkin, seperti yang terjadi pada buku Gurita Cikeas, adalah buku bersangkutan dibajak dan disebarkan via toko kecil atau bahkan pedagang kaki lima. Persebaran satu buku tersebut boleh jadi tetap akan meluas. Tetapi apakah penerbit tak akan kapok 
menerbitkan buku dengan tema kontroversial serupa menjadi soal yang sama sekali lain pasalnya merekalah yang kemudian dirugikan dari berbagai sisi. Lagi pula, pelarangan tak selalu berkontribusi bagi ketenaran kontinyu sebuah judul. Boleh jadi, sebagaimana pada kasus buku Allah, Liberty and Love karya Irshad Manji, kendati mengundang perhatian publik pada satu waktu namun sebegitu hiruk-pikuk protes keras dari ormas Islam tak lagi diberitakan, buku ini pun hilang begitu saja dari benak publik. Tak sampai mendorong khalayak ramai berjubel-jubel mencarinya.

Mengapa sentralisasi Gramedia berpengaruh besar dalam hal ini? Sebelum mengalami sentralisasi, buku dapat disalurkan kepada toko-toko Gramedia secara terpisah-pisah. Tiap-tiap toko memiliki bagian pembeliannya masing-masing. Bila satu buku tak diterima di satu toko, toko lain masih mungkin untuk menerimanya. Lantas apabila toko-toko Gramedia lain sudah mengedarkan buku terkait, toko yang sebelumnya menolak besar kemungkinan akan menerima buku tersebut. Satu distributor menyebutnya sebagai strategi mengepung dan menyerbu Gramedia. Tetapi hal serupa tak mungkin dilakukan sekarang. Keputusan di Gramedia saat ini diambil secara terpusat oleh divisi MDHO (Merchandising Head Officer) yang membawahi tiga orang staf STO (Standing Order) yang bertugas mengkaji kelayakan serta menaksir penempatan dan jumlah oplah satu buku baru yang ditawarkan kepada Gramedia. Bertanggung jawab atas risiko-risiko yang mungkin didatangkan sebuah buku baru kepada perusahaan, divisi ini punya otoritas sekaligus beban menentukan buku akan diterima di seluruh jaringan Gramedia yang sebanyak ratusan toko atau tidak. Menengahi antara penerbit dan jaringan toko buku, distributor juga kini biasa mengamanatkan bagian pembelian menghimbau penerbit agar mendiskusikan buku dengan pihaknya sebelum mulai memproduksinya. Punya kepentingan supaya penerbit produktif, bukunya diterima toko, serta kalau memungkinkan laris, distributor menjadi mekanisme saringan pertama yang memastikan kelayakan satu judul diterbitkan. Mengikuti banyaknya kasus buku jiplakan yang dalam istilah mereka spanyol-separo nyolong-buku sama diterbitkan dengan sampul berbeda, pihak pembelian lebih lumrah bertugas memastikan penerbit tidak sembrono dengan materi bukunya. Namun pada kesempatan yang sama, biasa pihak distributor akan mengingatkan juga penerbit agar tidak menyentuh tema-tema sensitif yang ditolak oleh Gramedia.

Namun yang juga tak boleh kita abaikan adalah faktor kemudahan memproduksi buku belakangan ini yang berujung pada membeludaknya jumlah terbitan. Setiap bulan Gramedia ditaksir menerima ribuan judul buku baru. Dengan membanjirnya buku termasuk dari pihak Gramedia sendiri yang tak dibarengi pertambahan lahan untuk toko buku, artinya, pihak toko sendiri tak akan kehilangan atau bahkan terbantu apabila mereka dimungkinkan untuk menolak sejumlah judul yang dipasok kepadanya. Penerbit membutuhkan toko buku. Namun, sebaliknya, bukubuku yang dipasok penerbit, bagi jaringan hilir dalam perbukuan utama ini, adalah hal yang amat mudah tergantikan. Ditambah lagi, kondisinya kini jumlah toko buku di luar Gramedia terus-menerus berkurang yang umumnya disebabkan karena salah pengelolaan. Boleh jadi, keberadaan ormas-ormas yang dibayangkan selalu memasang mata terhadap pelecehan agama menghalau Gramedia mengedarkan buku-buku yang dianggap tabu. Namun hal ini hanyalah salah satu di antara aliansi kekuatan yang mendorong buku dalam praktiknya tak bisa menjumpai khalayak pembacanya. 
Dalam skema kepenataan baru ini, sialnya pula, seseorang yang berharap dapat menemukan satu-dua pihak untuk dilawan demi merombak keadaan tak akan benarbenar menemukan siapa pun. Berbeda halnya dengan masa sebelumnya - pasca-Orde Baru dan pra-2012 - di mana pengaturan buku terkesan tak disangga apa pun kecuali pertimbangan menjaga kewibawaan segelintir elite yang bernaung dalam satu tubuh lembaga yang jelas. Buku-buku yang melanggar konvensi diskursif tertentu kini bukannya dilarang beredar melainkan tidak bisa beredar. Orang boleh menganggap dua hal ini - dilarang dan tak bisa beredar-sama saja. Kendati demikian, saya menekankan keduanya berbeda. Pasalnya, efek semiosisnya berbeda. Pelarangan akan membersitkan kesan ada satu rezim otoriter yang sewenang-wenang dan patut digugat. Tak heran bila pelarangan akan berujung pada perlawanan kolektif. Namun ketidakbisaan mengisyaratkan kekeliruan antara ada di pihak sang pelaku sendiri atau, memang, kondisi besarnya yang impersonal dan tak ada yang punya kuasa atasnya tak memungkinkan satu wacana berkembang.

Situasinya kini, lebih lanjut, ketidakmungkinan buku-buku yang mengangkat wacana tertentu untuk terdiseminasi lebih disangga oleh persilangan kepentingan yang semrawut, saling mengapit, dan lagi impersonal. Semua pihak adalah korban dari satu sirkulasi yang tak bisa dikendalikan siapa pun melainkan konsekuensi dari totalitas kehadiran semua aktor pada medan terkait. Penerbit, membutuhkan keuntungan finansial dan keberlangsungan usahanya, akan menghindari naskah-naskah yang dikiranya malah akan mencederai kepentingannya ini. Distributor, menghendaki penerbit terus-menerus menghasilkan buku, akan mengarahkannya untuk menghindari naskah-naskah yang berpotensi ditolak beredar. Jaringan toko buku utama menghendaki perusahaannya yang sudah besar aman dari situasi-situasi riskan serta, dapat diduga, nyaman apabila tak harus mengurus buku yang jumlahnya terlalu banyak. Dan, bila kita tambahkan elemen-elemen masyarakat yang mampu memobilisasi massa berbasis sentimen agama, mereka memperoleh rasionalisasi untuk mengancam pihak-pihak yang terlibat dalam proses penerbitan bila tabu agama yang dianggapnya keterlaluan dan tak mungkin didebat dilanggar.

Dalam kondisi ini, muluk-muluk pula bila berpikir satu pihak yang menerbitkan buku yang tak bisa beredar akan memperoleh keuntungan simbolik ala seorang martir yang mendorongnya menerbitkan buku semacam berkesinambungan. Keuntungan simbolik yang produktif-dalam artian mendorong satu pihak mengulang-ulang aktivitas tertentu meski ditabukan - hanya mungkin untuk direalisasikan di bawah sebuah kondisi di mana keuntungan pada dimensi ini dapat dipertukarkan dengan keuntungan praktis - ekonomik, sebut saja-yang menyanggupkannya menyambung hidup, dan hal ini tak kita jumpai pada kasus kita. Yang malah terjadi, sebagai akibat dari tatanan kontemporer perbukuan yang tak lagi dihadapkan dengan laranganlarangan dari aparatus negara, penerbitan buku-buku yang melanggar diskursus arus utama ditanamkan sebagai lelaku yang kontraproduktif; tak akan menghasilkan apa pun ataupun menyebabkan perbedaan yang berarti, dan boleh jadi justru merugikan dirinya sendiri tanpa kemungkinan akan adanya insentif di masa mendatang. 


\section{SIMPULAN}

\section{Di antara yang Tertata dan yang Tak Tertata}

Di manakah lantas kedudukan buku-buku bertajuk komunisme sebagai sebuah tuturan yang mengartikulasikan wacana yang pernah dan rasanya masih dianggap di luar kenormalan ini? Kita menjumpai buku-buku bertema komunisme berada pada ketegangan yang alot dan menyulitkan kita, sebenarnya, untuk mendudukkannya pada satu tempat yang pasti dalam rezim kepenataan sekarang ini. Di satu sisi, ia adalah tema istimewa yang memungkinkan buku yang mengulasnya memperoleh perhatian yang lebih dibandingkan buku-buku kategori sosial-humaniora lainnya. Di sisi lain, dengan tema yang digadangnya yang membangkitkan asosiasi negatif yang ditanamkan secara sistematis dalam waktu lama oleh Orde Baru, dan masih cukup bermanfaat bagi satu kalangan masyarakat untuk membangun identitasnya dengan terus menempatkannya sebagai liyan, adalah sangat mungkin sewaktu-waktu buku dengan tema ini tercekal; apalagi dengan godaan dari pihak penerbit untuk menonjolkan justru aspek yang menyebabkannya ditabukan rezim di masa silam lantaran hal ini bisa merenggut perhatian pembaca buku. Yang bisa dipastikan, hambatan untuk beredar itu memang dialami penerbit kendati tidak dalam bentuk regulasi represif melainkan himbauan dari pihak distributor maupun toko buku bahwa terbitannya berpotensi tak bisa didistribusikan. Kerugian, kalau ia tetap menerbitkannya dan mengemasnya sekontroversial mungkin, bukan lagi dampak dari irasionalitas rezim melainkan tindakannya sendiri. Terjadi apa yang boleh jadi tepat untuk dikonsepkan sebagai individualisasi kesalahan. Satu penerbit sempat mengalaminya. Sentimen-sentimen cela terhadap komunisme pun pada kenyataannya masih berlaku dan mungkin untuk dimobilisasi kapan pun kepentingan tertentu punya momentum untuk memanfaatkannya.

Kita, pada praktiknya, masih menjumpai buku Herlambang-yang kita gunakan sebagai bahan perbandingan - dijual dan menuai minat pembaca yang cukup luas salah satunya karena menguak keterlibatan salah seorang budayawan berpengaruh dalam pembentukan wacana antikomunisme. Buku Tan Malaka, Gerakan Kiri dan Revolusi Indonesia Jilid Empat karangan Harry Poeze kita jumpai diterbitkan Yayasan Obor pada 2014. Namun, penting dicatat, diskusi buku ini di berbagai kota dihentikan karena tuntutan ormas-ormas Islam. Di Semarang, diskusi ini sempat dibubarkan pula namun mengikuti banyaknya surat dan tuntutan terbuka yang dilayangkan kepada Gubernur Jawa Tengah, Ganjar Pranowo, diskusi akhirnya dilangsungkan di tempat lain dan dihadiri langsung oleh gubernur. Kita melihat, artinya, wacana ini dalam beberapa waktu ke depan masih punya peluang diproduksi dan diartikulasikan melalui buku; tetapi, lebih spesifiknya sebenarnya, diartikulasikan dalam buku ulasan keilmuan pasalnya dalih kajian akademik ternyata masih cukup dianggap sebagai alasan yang tepat memperbincangkan tema ini. Kendati demikian, tetap saja tak akan pernah bisa dipastikan bagaimana nasib tema-tema buku yang mengulas komunisme di masa mendatang. Batasan antara hal yang sebaiknya diperbincangkan dan tidak sebaiknya diperbincangkan selalu bergolak oleh benturan-benturan yang secara nyata berlangsung dan bukannya satu struktur yang mengawang dan ada tanpa perlu hadir di antara proses-proses historis. Di satu posisi di luar rantai penerbitan sana, ada kekuatan-kekuatan yang masih melestarikan sentimen untuk alasan-alasan yang 
rasional setidaknya dalam rangka memuaskan hasrat kolektif mendambakan sosok liyan yang jahat; sementara pada umumnya tak ada alasan pragmatis bagi aparatus pemerintahan untuk membela mereka yang dianggap mengadvokasi komunisme dan hanya ada alasan pertimbangan menjaga hak warga berserikat yang pada kebanyakan waktu bukan dalih yang cukup kuat memotivasi mereka. Lantas di dalam rantai penerbitan sendiri, belakangan berkembang norma-norma menjauhi terbitan-terbitan riskan yang dianggap akan kontraproduktif bagi keberlangsungannya sendiri.

Artikulasi wacana komunisme rentan terbungkam oleh persilangan-persilangan yang membentuk rezim praktik baru ini. Namun di sisi lain, saya juga akan mengatakan, ia punya peluang untuk senantiasa dapat menghindari dirinya terjerumus ke dalam kategori teks yang tak dapat dituturkan. Di tengah-tengah ranah produksi buku di mana rasionalitas finansial menjadi pertimbangan yang mendasar, ia dapat menuai respons kuat audiens pembeli buku dengan temanya yang menyerempet ambang wilayah yang tak dapat diperbincangkan bebas. Dihadapkan dengan kekuatan-kekuatan yang menganggapnya sebagai liyan yang seyogianya ditumpas, ia dapat memosisikan diri sebagai kajian akademik yang sedari Orde Baru merupakan dalih efisien berkelit dari pantauan rezim atau menempatkan dirinya pada posisi di mana tak akan ada insentif bagi kekuatan yang meliyankannya bila memobilisasi kekuatan untuk melucutinya. Pada dasarnya, peluang-peluang selalu terbuka. Seseorang punya alasan untuk skeptis dengan tempat bagi wacana non-arus utama ini dalam ranah perbukuan masa mendatang. Namun ia juga punya alasan untuk optimistis. Apa yang menyelenggarakan formasi wacana tertentu, sekali lagi, bukanlah bagaimana ia dikonsepkan oleh satu-dua otoritas melainkan bagaimana praktik di antara otoritasotoritas ini bersilang-sengkarut satu sama lain. Merupakan implikasi dari benturan dan negosiasi antarkekuatan agar masing-masing tetap dapat bertahan serta bila mungkin berjalan beriringan, modus kepenataan merupakan formasi yang majemuk, tak terduga, dan memiliki berbagai celah. Dan, yang bisa kita jamin di sini, tak akan final alias selalu berada dalam proses pembentukan.

Di sinilah, di antara modus kepenataan yang tampak ketat-saya perlu membubuhkan sebagai catatan akhir mempertimbangkan Foucault acap disalahpahami tak memberikan ruang bagi perubahan (Fraser) - pihak-pihak yang terlibat sebenarnya justru memiliki proporsi perannya masing-masing dalam pembentukan kenyataan yang dihidupi. Rezim, kita insaf, bukanlah rezim yang berdiri tegak dengan sendirinya. Ia ada karena-dan hanya karena-dijalani dan menjadi aliansi kepentingan yang tak pernah benar-benar kokoh di antara para aktornya.

\title{
DAFTAR PUSTAKA
}

\author{
"1.340 Buku Sejarah Dibakar." Tempo Interaktif, 2007, \\ http:/ / www.tempo.co/read/news/2007/07/30/057104628/1340-Buku-Sejarah-. \\ “Adikarya Ikapi, 'Sang Penyelamat".'” Kompas, 2002. \\ “Buku-Buku Ini Dilarang!” Kompas, 2009.
}


"Digeruduk Ormas Islam, Diskusi Tan Malaka Bubar." Tempo Interaktif, 2014, http://www.tempo.co/read/news/2014/02/07/078552156/Digeruduk-OrmasIslam-Diskusi-Tan-Malaka-Bubar.

Durkheim, Emile. The Rules of Sociological Method. Edited by Steven Lukes, Translated by W.D. Halls, The Free Press, 1982.

Foucault, Michel. Discipline and Punish: The Birth of Prison. Translated by Alam Sheridan, Vintage Books, 1977.

---. "Question of Method." The Foucault Effect: Studies in Governmentality, edited by Graham Burchell et al., University of Chicago Press, 1991, pp. 73-86.

---. The Birth of Biopolitics: Lectures at the Collège de France, 1978-1979. Palgrave MacMillan, 2008.

Fraser, Nancy. Unruly Practices: Power, Discourse and Gender in Contemporary Social Theory. The University of Minnesota Press, 1989.

“Ganjar Pranowo Diapresiasi, Hadiri Buku Tan Malaka Di Tengah Kuatnya Penolakan.” Rakyat Merdeka Online, 2014, http://www.rmol.co/read/2014/02/19/144438/Ganjar-Pranowo-Diapresiasi,Hadiri-Bedah-Buku-Tan-Malaka-di-Tengah-Kuatnya-Penolakan-.

Herlambang, Wijaya. Kekerasan Budaya Pasca 1965: Bagaimana Orde Baru Melegitimasi Anti-Komunisme Melalui Sastra Dan Film. Marjin Kiri, 2014.

Heryanto, Ariel. State Terrorism and Political Identity in Indonesia: Fatally Belonging. Routledge, 2006.

Latour, Bruno. The Pasteurization of France. Harvard University Press, 1988.

"Massa Bubarkan Paksa Kongres Papernas." Tempo Interaktif, 2007, http://www.tempo.co/read/news/2007/01/19/05891642/Masa-BubarkanPaksa-Kongres-Papernas.

McGregor, Katharine E. History in Uniform: Military Ideology and the Construction of Indonesia's Past. nus Press, 2007.

"MK Cabut Kewenangan Kejaksaan Melarang Buku." Vivanews, 2010, http:/ / nasional.news.viva.co.id/news/read/182720-mk-cabut-kewenangankejaksaan-melarang-buku.

“Orde Baru 31 Tahun, 2000 Buku Dibredel.” Majalah Tempo, Sept. 1996.

Pengajuan Permohonan Pengujian UU No. 4/PNPS Tentang Pengamanan Terhadap BarangBarang Cetakan Yang Isinya Dapat Mengganggu Ketertiban Umum Terhadap Undang$\begin{array}{llll}\text { Undang Dasar } & \text { Republik }\end{array}$ http:/ / www.kontras.org/index.php?hal=siaran_pers\&id=1011.

Pengamanan Terhadap Barang-Barang Cetakan Yang Isinya Dapat Mengganggu Ketertiban Umum. UU No. 4/PNPS/1963, 1963. 